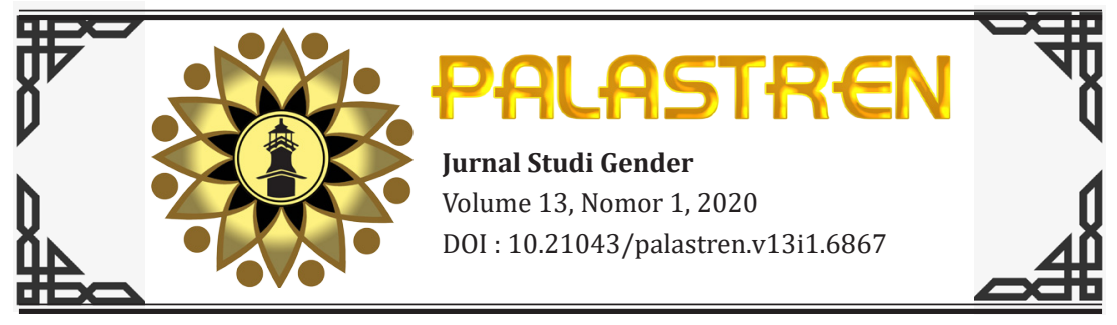

\title{
MENENUN BAGI PEREMPUAN MELAYU RIAU: ANTARA PELUANG USAHA DAN PELESTARIAN BUDAYA
}

\author{
Hasbullah \\ Universitas Islam Negeri Sultan Syarif Kasim Riau, Indonesia \\ hasbullah@uin-suska.ac.id \\ Wilaela \\ Universitas Islam Negeri Sultan Syarif Kasim Riau, Indonesia \\ wilaela@uin-suska.ac.id \\ Riska Syafitri \\ Sekolah Tinggi Agama Islam Ar-Ridho Bagan Siapiapi, Indonesia \\ riskasyafitri91@gmail.com
}

\begin{abstract}
Abstrak
Artikel ini bertujuan untuk menjelaskan aktivitas menenun bagi Perempuan Melayu yang dilihat dari dua sisi, yaitu peluang usaha dan pelestarian budaya. Metode yang digunakan dalam Penelitan ini adalah metode kualitatif dengan teknik wawancara terhadap perajin tenun, tokoh agama, dan tokoh masyarakat. Hasil kajian ini menyimpulkan bahwa peluang usaha muncul sebagai akibat dari otonomi daerah dan kebijakan Pemerintah Provinsi Riau untuk menggali berbagai khasanah lokal khas Riau. Pada saat ini sudah muncul pusat-pusat penghasil kain tenun dan juga sentra-sentra yang menjual kain tenun. Sedangkan pelestarian budaya merupakan efek dari kebijakan tersebut yang membuat para perajin tenun kembali bergairah untuk menekuninya karena memiliki nilai ekonomis. Pewarisan keterampilan menenun tidak lagi hanya terbatas pada keluarga perajin,
\end{abstract}


melainkan juga sudah meluas kapada masyarakat yang meminatinya. Pemerintah mendukung dengan berbagai program dan kebijakan, seperti memakai songket dalam acara tertentu dan gerakan Riau bertanjak, agar keterampilan menenun tetap bertahan dan berkembang di tengah masyarakat Melayu Riau.

Kata Kunci: Perajin tenun, Perempuan melayu, dan Pelestarian budaya.

\section{Abstrak}

This article aims to explain the weaving activity for Malay Women from two sides, namely business opportunities and cultural preservation. The method used in this research is qualitative with interview techniques as the main data collector. Primary data were obtained from interviews with informants consisting of weavers, religious leaders, and community leaders. The results of this study concluded that business opportunities arise as a result of regional autonomy and the Riau Provincial Government's policy to explore various local specialties of Riau. At present there are centres that produce and sell woven fabrics. While cultural preservation is the effect of the policy which makes the weaving crafters eager to pursue again since it has economic value. Inheritance of weaving skills is no longer limited to crafters' families only, but has also expanded to those who are interested in it. The government supports this through various programs and policies, like wearing songket in certain events and the Riau Bertanjak movement, so that weaving skills remain sustainable and thrive in the Riau Malay community

Keywords: Weaving crafters, Malay women, and cultural preservation

\section{A. Pendahuluan}

Keterlibatan perempuan dalam sektor ekonomi bukanlah merupakan sesuatu yang baru, mereka sudah terlibat sejak lama dan menekuni berbagai jenis pekerjaan. Meskipun dalam banyak pandangan kebudayaan perempuan ditempatkan di sektor domestik, namun kenyataannya sumbangan mereka dalam ekonomi rumah tangga tidak dapat dinafikan (Masud \& Hamid, 
2004). Ada banyak alasan atau motivasi kaum perempuan terlibat dalam sektor ekonomi, mulai dari membantu menghidupi keluarga, sampai kepada untuk memiliki otonomi keuangan agar tidak selalu tergantung pada pendapatan suami. Dalam kenyataannya, perempuan cenderung bekerja lebih lama dengan pendapatan yang relatif lebih rendah dibandingkan dengan lakilaki (Papanek dalam Ihromi, 1995; Arifin, 1994; Dewayanti \& Chotim, 2004; Idris, 2008). Bagaimanapun beratnya beban kerja mereka dan kecilnya imbalan yang diperoleh, kegiatan ini tetap mereka tekuni karena mutlak diperlukan, di samping untuk membantu suami menambah pendapatan juga sangat berarti bagi mempertahankan kelangsungan hidup mereka yang selalu berada di garis subsistensi. Hal ini merupakan indikator betapa sentralnya posisi perempuan dalam ekonomi rumah tangga. Kondisi ini merupakan dorongan penyadaran peran perempuan untuk berkiprah di sektor publik.

Perempuan terlibat aktif dalam menjalankan berbagai kegiatan ekonomi, baik sebagai buruh upahan, karyawan, dan juga cukup banyak yang memiliki usaha mandiri. Usaha mandiri yang dikembangkan oleh kaum perempuan tentu saja tidak jauh dari keahlian yang mereka miliki, seperti menjual makanan, pakaian, menjahit, menenun, dan lain-lain. Usaha yang mereka dirikan bukanlah usaha yang besar, melainkan usaha mikro dan kecil. Meskipun demikian, kehadiran jenis usaha ini jelas sudah terbukti mampu mempertahankan kondisi ekonomi rumah tangga seperti yang terjadi dalam krisis moneter di Indonesia tahun 1997 (Puspitawati dkk., 2012).

Usaha mandiri dipandang dari satu sisi memungkinkan bagi perempuan untuk memulai dan menghentikan kegiatan tersebut sesuai dengan kebutuhan keluarga. Tetapi di sisi lain ini merupakan hambatan bagi perkembangan usaha dalam meningkatkan pendapatan. Pada umumnya perempuan yang menggeluti sektor informal seperti berdagang, jasa, dan sektor lainnya masih memiliki banyak kendala, antara lain disebabkan keterbatasan atau tidak dimilikinya keterampilan khusus untuk mengelola pekerjaannya, di samping keterbatasan mobilitas 
fisik mereka dalam menjalankan aktivitas (Dewayanti dkk., 2003; Dewayanti \& Chotim, 2004). Dalam menekuni usaha, perempuan banyak terlibat dalam sektor informal untuk mendukung ekonomi keluarga dibandingkan laki-laki.

Keterlibatan perempuan dalam sektor informal dapat ditemukan di setiap kawasan negeri ini. Mereka melakukan berbagai pekerjaan untuk mendukung ekonomi keluarga, antara lain sebagai petani (Fariyanti, 2008; Husin \& Sari, 2011; Kusnadi, 2005; Siddik dkk., 2013), nelayan (Pancasasti, 2008), dan perajin (Ayesha, 2016; Nursiah dkk., 2017; Prasetyo, 2007). Demikian juga halnya dengan perempuan Melayu di Riau, sudah sejak lama mereka menekuni berbagai aktivitas ekonomi, baik sebagai petani, pedagang, maupun perajin (Djohan dkk., 2003). Salah satu kerajinan tradisional yang ditekuni oleh perempuan Melayu Riau adalah menenun.

Berbagai kerajinan tradisional dan kearifan lokal dihidupkan kembali pada era otonomi daerah. Hal ini bertujuan agar setiap daerah memiliki ciri khas tertentu yang dapat dibedakan dengan daerah lain dan sekaligus dapat meningkatkan pendapatan daerah dan masyarakat. Salah satu kebijakan Pemerintah Provinsi Riau adalah memperkenalkan songket/tenun Melayu Riau sebagai oleh-oleh atau cenderamata khas dari Riau. Kebijakan ini membuat aktivitas menenun kembali bergairah yang sebelumnya tidak begitu diperhatikan (Andani, 2017; Sari, 2015).

Penelitian tentang menenun bagi perempuan Melayu Riau ini menggunakan pendekatan kualitatif bertumpu pada data yang dikumpulkan melalui observasi dan wawancara mendalam. Kajian ini dilakukan di Desa Bukit Batu Kabupaten Bengkalis Provinsi Riau. Kaum perempuan daerah ini sudah sejak lama menekuni keterampilan yang diwariskan secara turun temurun. Wawancara mendalam dilakukan dengan perajin tenun (15 orang), tokoh agama (3 orang), tokoh masyarakat (5 orang), dan suami/kepala rumah tangga (15 orang). Melalui pendekatan tersebut dapat menjelaskan tentang aktivitas menenun bagi perempuan Melayu yang memiliki fungsi ekonomi dan sekaligus melestarikan kerajinan tenun Melayu Riau. 


\section{B. Pembahasan}

\section{Budaya Menenun di Masyarakat Melayu Riau}

Menenun merupakan salah satu pekerjaan yang banyak dilakukan oleh kaum perempuan di Riau, khususnya wilayah bekas Kerajaan Siak, seperti Bukit Batu di Kabupaten Bengkalis, Kampung Rempak dan Kampung Dalam di Kabupaten Siak, Kota Pekanbaru dan Kota Dumai. Menurut sejarah, tenun yang hadir di masyarakat Melayu Riau pertama kali diperkenalkan oleh seorang perajin yang datang dari Kerajaan Terengganu Malaysia pada masa Kerajaan Siak di bawah pimpinan Sultan Sayid Ali. Wan Siti Binti Wan Karim (seorang penenun yang cakap dan juga terampil dalam bertenun di Terengganu), dibawa ke Siak Sri Indrapura untuk mengajarkan bagaimana cara menenun kain songket (Dekranasda Provinsi Riau, 2008). Keterampilan ini sudah dikenal sejak Kerajaan Siak dan diwariskan secara turun temurun serta menjadi kerajinan tradisional khas masyarakat Melayu Riau (Luthfi dkk., 1977: 177).

Kain yang dihasilkan dari pekerjaan menenun disebut dengan kain songket. Kata songket berasal dari kata sungkit yang berarti mencungkil, dan juga mengandung makna proses mengait. Kedua proses tersebut (menyungkit dan mengait) merupakan proses utama yang dilakukan dalam menenun. Ada beberapa istilah yang digunakan oleh masyarakat daerah lain untuk menyebut proses ini, seperti di Palembang mengatakan kata songket berasal dari kata songko yang berarti saat orang pertama menggunakan benang emas sebagai hiasan dari sebuah ikat kepala. Di Bali kata nyuntik dalam proses menenun dapat dihubungkan dengan merencanakan motif. Di Sumbawa arti songket khususnya kain tenun yang dihias dengan benang emas dan perak. Pemaknaan istilah songket tampaknya merujuk kepada teknik pembuatan yang berbeda-beda yang dilakukan oleh masing-masing perajin setiap daerah (Suwati, 1996).

Pada saat sekarang ini sentra-sentra tenun dengan mudah ditemukan di berbagai kawasan di Provinsi Riau, baik dalam bentuk perkumpulan/KUB (Kelompok Usaha Bersama) 
maupun milik perorangan. Perempuan Melayu Riau senantiasa mewariskan budaya menenun kepada generasi selanjutnya, meskipun pada era sebelum reformasi menenun bukanlah pekerjaan atau profesi yang menjanjikan. Dengan demikian, pekerjaan ini pada masa lalu hanyalah merupakan aktivitas sampingan yang dilakukan oleh perempuan Melayu yang tidak memiliki pekerjaan tetap. Berbeda dengan kondisi pada masa sekarang di mana profesi sebagai penenun dapat menghasilkan pendapatan yang bisa diandalkan bagi ekonomi rumah tangga. Faktor inilah yang menyebabkan bermunculannya usaha kecil dan menengah dalam bidang ini.

Salah satu daerah yang mengembangkan dan melestarikan kerajinan tradisional ini sejak masa lalu adalah Desa Bukit Batu. Desa ini terdapat di Kecamatan Bukit Batu Kabupaten Bengkalis, dan memiliki hubungan yang erat dengan Kerajaan Siak (Luthfi dkk., 1977). Peran komunitas penenun kawasan ini amat penting dalam pengembangan dan pewarisan keterampilan menenun. Sebagian dari mereka dijadikan sebagai tutor oleh Dewan Kerajinan Nasional Daerah (Dekranasada) Kabupaten Bengkalis yang mengajarkan keterampilan menenun untuk masyarakat di daerah lain (Salmah, wawancara, 8 Oktober 2019). Di samping itu, ada banyak warga desa ini yang sudah menetap di Dumai, Siak, dan Pekanbaru yang juga mengembang kerajinan ini (Wan Fitri, wawancara, 10 Oktober 2019). Produksi kain tenun/songket yang dihasilkan oleh perajin desa ini dijual ke berbagai daerah di Provinsi Riau, bahkan sampai ke luar provinsi.

Perempuan Melayu di daerah ini sudah menekuni pekerjaan ini sejak lama dan diwariskan secara turun temurun. Tidak ada sekolah atau lembaga tertentu yang mengajarkan keterampilan ini kepada generasi muda. Keterampilan menenun diajarkan secara tradisional oleh keluarga perajin kepada anak perempuan mereka. Oleh sebab itu, dari waktu ke waktu keterampilan menenun tetap dikuasai atau ditekuni oleh keluarga yang sebelumnya menekuni aktivitas tersebut. Jika pun ada perajin baru jumlahnya tidaklah terlalu banyak. Sejalan dengan waktu, jumlah perajin semakin meningkat dikarenakan 
profesi menenun mulai menjanjikan dan muncullah perajinperajin tenun hampir di seluruh kawasan Provinsi Riau, terutama daerah bekas wilayah Kerajaan Siak.

\section{Menenun Sebagai Peluang Usaha}

Kondisikeluarga perajintenundiDesa BukitBatumerupakan salah satu bentuk gambaran keluarga miskin di Indonesia. Mereka harus melakukan pekerjaan untuk membantu suami dalam memenuhi kebutuhan rumah tangga. Menurut penjelasan informan (wawancara, 08-13 Oktober 2019), baik laki-laki maupun perempuan dalam rumah tangga sama-sama berkewajiban dalam memenuhi kebutuhan rumah tangga. Fenomena ini menjelaskan bahwa kaum perempuan sudah terbiasa bekerja untuk membantu suami dalam memenuhi keperluan rumah tangga, sehingga persoalan ekonomi tidak selamanya bergantung kepada kaum laki-laki atau menjadi monopoli para suami (Harun AR, 2015). Meskipun demikian, pandangan bahwa laki-laki (suami) sebagai pemimpin rumah tangga dan berkewajiban memenuhi nafkah keluarga tetap dipegang teguh (Alizar, wawancara, 9 Oktober 2019). Dengan demikian, peran perempuan (istri) dipandang lebih sebagai "pelengkap" untuk membantu suami dalam mencukupi keperluan sehari-hari. Pandangan tersebut melahirkan pembagian pekerjaan atau peran serta tanggung jawab yang dalam perspektif feminisme merugikan kaum perempuan (Fakih, 1996; Megawangi, 1999). Namun, perempuan di daerah ini sudah terbiasa melakukannya sehingga tidak muncul kritikan atau protes dengan kondisi yang ada, meskipun mereka harus melakukan pekerjaan yang lebih banyak dan waktu yang digunakan untuk bekerja lebih lama. Kondisi ini dipandang oleh kaum feminis sebagai penindasan terhadap kaum perempuan yang perlu dibebaskan (Megawangi, 1999: 150).

Perempuan Melayu sudah terbiasa ikut serta dalam meningkatkan ekonomi keluarga, mereka melakukan berbagai pekerjaan, baik bekerja membantu suami atau bekerja secara mandiri. Bagi perempuan yang memiliki keterampilan tertentu, misalnya menenun, mereka akan meningkatkan pendapatan 
keluarga melalui pekerjaan sebagai penenun. Seperti yang sudah disebutkan di atas, sejalan dengan semangat otonomi daerah, setiap daerah berlomba-lomba menggali berbagai potensi daerahnya yang dapat dijadikan ciri khas sekaligus bernilai ekonomis. Potensi daerah yang dimanfaatkan dapat berupa kearifan lokal, kerajinan tradisional, kulier tradisional, dan sebagainya.

Salah satu kerajinan tradisional yang diangkat oleh Pemerintah Provinsi Riau adalah songket atau tenun Melayu Riau. Pemerintah memberi perhatian khusus untuk kerajinan ini sehingga muncul sentra-sentra songket Melayu Riau. Pada masa lalu, kerajinan ini hanya dikerjakan di rumah-rumah dan tidak banyak yang mau melakukannya karena nilai ekonomisnya rendah. Namun, sejalan dengan kebijakan tersebut, mulai muncul gerai-gerai yang menjual kain songket Melayu Riau sehingga terbuka peluang usaha bagi masyarakat, khususnya kaum perempuan. Di samping itu, minat generasi muda mempelajari keterampilan menenun juga meningkat dan tidak lagi terbatas hanya pada keluarga perajin.

Pilihan-pilihan kerja dan usaha yang diambil perempuan tidak terlepas dari pola-pola pemenuhan keperluan keluarga yang muncul tidak hanya disebabkan oleh konstruksi budaya dalam masyarakat, melainkan juga akibat dari penetrasi sistem kapitalis ke dalam ekonomi pedesaan yang menempatkan desa sebagai wilayah periferi ekonomi yang miskin. Untuk memenuhi kebutuhan keluarga dan menigkatkan pendapatan, maka seluruh anggota keluarga dilibatkan untuk menjaga kelangsungan hidupnya (Egayanti dkk., 2018). Dalam hal ini, keluarga-keluarga perajin tenun menjalani lebih dari satu macam kerja dan usaha demi pemenuhan kebutuhan keluarga (Observasi, 08-13 Oktober 2019). Demi efisiensi, kerja-kerja produktif perempuan perajin tenun lebih banyak diposisikan di ranah domestik agar dapat sekaligus menyelesaikan tugas domestik (Siti Zubaidah, wawancara, 10 Oktober 2019).

Pekerjaan menenun dikerjakan oleh kaum perempuan di rumah masing-masih atau paling jauh mereka mengerjakan di 
gedung yang disediakan oleh pemerintah untuk usaha ini. Tapi yang jelas, jarak gedung dengan rumah mereka tidak terlalu jauh. Pilihan usaha ini sangat menguntungkan bagi kaum perempuan, karena secara ekonomis mereka dapat menghasilkan uang dan sekaligus dapat menyelesaikan tanggung jawab sebagai ibu rumah tangga sehingga tidak menimbulkan pandangan yang negatif di tengah masyarakat (Mayaswari \& Yasa, 2015).

Untuk menekan biaya produksi, pekerjaan menenun melibatkan seluruh anggota keluarga, baik suami maupun anakanak mereka mengambil peran tersendiri dalam proses tersebut. Namun, ada juga yang melibatkan orang lain dengan sistem upah untuk tahapan tertentu dalam proses menenun. Pola seperti ini merupakan satu strategi untuk menumbuhkan rasa tanggung jawab dari seluruh anggota keluarga terhadap beban ekonomi yang harus dipikul. Di samping itu, secara tidak langsung cara kerja seperti ini menjadi salah satu bentuk proses transformasi pengetahuan ke generasi muda. Mereka mempelajari keterampilan menenun dengan cara membantu orang tua atau keluarga mereka yang sedang mengerjakannya. Cara seperti tentu saja efektif dalam mentransformasi pengetahuan karena mereka dilibatkan langsung dalam setiap tahapan. Transformasi pengetahuan dan transfer keterampilan menenun ke generasi muda dapat dilihat di sentra dan gerai produksi tenun, baik di Bukit Batu, Dumai, atau Pekanbaru. Di antaranya "Rumah Tenun Wan Fitri" dan "Rumah Tenun Songket Melayu Winda". Kedua rumah tenun ini berada di Pekanbaru dan mengajarkan keterampilan songket kepada anak muda, baik perempuan maupun laki-laki.

Rumah Tenun Wan Fitri yang terletak di Jalan Kayu Manis Pekanbaru merupakan salah satu bukti diseminasi keterampilan bertenun dari tradisi bertenun kaum perempuan Bukit Batu. Pemilik rumah tenun, Wan Azizah adalah perempuan yang berasal dari Bukit Batu. Sejak berdirinya Provinsi Riau, ia dan keluarganya telah memulai menjadi perajin tenun di Pekanbaru. Namun usaha informal ini berjalan lambat karena tenun merupakan barang mewah, mahal dan eksklusif. Sekalipun 
Gubernur Soeripto memulai sosialisasi tenun, namun nasib kerajinan tenun belum berubah. Barulah setelah otonomi daerah, Pemerintah Riau mengkampanyekan tenun sebagai ikon Riau. Perubahan kebijakan ini berpengaruh pada produksi Rumah Tenun Wan Fitri pada tahun 2000an meningkat dengan cepat (Wan Fitri, wawancara, 10 Oktober 2019).

Karena kebijakan Pemerintah Daerah Riau tentang tenun atau songket sebagai identitas daerah, sentra-sentra tenun banyak berdiri di berbagai daerah. Tradisi tenun Bukit Batu pun menyebar ke Pekanbaru dan Dumai. Keduanya terkait karena sentra di Dumai merupakan rumah produksi tenun mesin di bawah brand Rumah Tenun Wan Fitri. Perkembangan produksi tenun Bukit Batu ini tidak saja dalam jumlah produksi kain tenun yang dihasilkan dalam suatu waktu, tetapi juga karena lahirnya produk turunan seperti asesoris, topi, barang cinderamata, taplak meja, syal, selendang, sepatu, tas, topi, dan lain-lain. Produk-produk turunan tersebut telah menumbuhkan kelompok pengrajin kreatif selain perajin tenun. Produk tenunan, seperti kain tenun tetap mewah sekalipun harganya lebih bervariatif karena tergantung dari motif dan teknik pembuatannya, menggunakan ATBM atau dengan mesin.

Dukungan pemerintah untuk mengembangkan usaha ini sangat besar, seperti menyediakan bantuan, mengadakan pelatihan, dan sebagainya. Namun, usaha ini sampai saat sekarang tetap tidak menunjukkan perkembangan yang menggembirakan karena pasar yang masih terbatas. Usaha mandiri yang dilakukan oleh perempuan Melayu sebagai usaha mikro dapat digambarkan sebagai usaha-usaha marginal dan subsisten. Usaha mikro sering ditandai dengan jenis transaksi yang dilakukan dalam jumlah kecil, transaksi sering dilakukan dengan orang-orang yang dikenal, kesepakatan yang dibangun bersifat langsung (face-to-face), berdasarkan pada kepercayaan, referensi pribadi, transaksi dilakukan antara dua orang atau lebih, tempat usaha kurang tetap, tidak dapat dilayani oleh perbankan, umumnya tidak memiliki legalitas usaha, memiliki aturan sosial sendiri, menggabungkan berbagai jenis pekerjaan 
yang sumber dayanya dimiliki dan dikendalikan sendiri oleh mereka untuk keperluan-keperluan yang sifatnya subsisten (Dewayanti \& Chotim, 2004; Rizky, 2008).

Bermunculannya sentra-sentra penjualan songket Melayu Riau dan para perajin baru merupakan satu tantangan tersendiri bagi perajin lama. Hal ini tentu saja berdampak pada persoalan pemasaran kain songket yang juga dirasakan sulit oleh para perajin, meskipun sudah ada dukungan dan kebijakan dari Pemerintah. Gerakan menggunakan songket bagi pegawai pemerintahan pada hari tertentu dan Gerakan Riau Bertanjak memang menjadi momen untuk bangkitnya dan terbuka peluang usaha ini. Namun, tentu saja tidak akan banyak memberikan efek ekonomi karena yang memerlukannya masih terbatas. Belum lagi adanya persaingan dari jenis songket lainnya dengan harga yang lebih murah, seperti Songket Silungkang (khas Sumatera Barat) dan kain serupa yang berasal dari produk Cina. Dengan demikian, diperlukan kreativitas yang lebih agar usaha ini tidak hanya sebatas sebagai usaha mikro dan subsisten, tetapi dapat dikembangkan sebagai usaha yang lebih besar dan nasional.

\section{Menenun sebagai Pelestarian Budaya}

Sejalan dengan otonomi daerah, pemerintah provinsi dan kabupaten di Riau berusaha untuk menggali potensi yang terdapat di daerah masing-masing, baik yang bernilai ekonomis, budaya, maupun pariwisata. Pemerintah berupaya menghidupkan kembali berbagai warisan tradisional yang mungkin sudah hilang atau mati suri. Salah satu budaya kerajinan tradisional Melayu Riau yang sudah dikenal luas dan masih bertahan sampai sekarang adalah kain songket atau disebut juga kain tenun. Melalui Dewan Kerajinan Nasional Daerah (Dekranasda), Pemerintah Provinsi dan Kabupaten berusaha untuk melestarikan dan memperkenalkan secara luas kerajinan ini. Oleh karena itu, program pelatihan dilakukan untuk menambah jumlah perajin dan pemerintahjuga membantu pemasarannya. Kebijakan inilah yang memunculkan sentrasentra tenun di berbagai kawasan di Provinsi Riau. 
Bagi masyarakat Bukit Batu, pekerjaan menenun bukanlah sesuatu yang baru. Masyarakat Bukit Batu sudah mengenal kerajinan ini dengan baik karena diwariskan secara turun temurun. Para orang tua mengajarkan keterampilan menenun kepada anak perempuan di kalangan keluarga mereka, karena aktivitas ini hanya ditekuni oleh kaum perempuan. Mereka telah mulai mengajar dan melatih keterampilan tersebut sejak anak memasuki usia remaja, yaitu dimulai ketika anak perempuan mereka berusia 13 tahun atau setelah menyelesaikan sekolah dasar. Aktivitas pelatihan ini dilakukan setelah anak mereka pulang dari sekolah, masa-masa luang, dan pada hari-hari libur sekolah. Proses belajar mengajar dilakukan secara bertahap dan langsung dibimbing oleh orang tua mereka. Proses pembelajaran dilakukan secara alami berdasarkan pengalaman mereka masa lalu. Hal ini dilakukan untuk membekali anak mereka dengan keterampilan tertentu (menenun) agar dapat digunakan untuk memenuhi keperluan hidup, baik sebelum maupun setelah berkeluarga (Salmah, 12 Oktober 2019). Pekerjaan menenun dianggap lebih "cocok atau sesuai" untuk kaum perempuan daripada kaum laki-laki, karena pekerjaan ini memerlukan tingkat kehati-hatian dan kesabaran yang tinggi. Anggapan ini, menurut Mansour Fakih (1996:11-12) mewakili perbedaan peran gender yang dianut masyarakat dan bukan merupakan "kodrat" atau "takdir" yang telah ditetapkan oleh Tuhan terhadap kaum perempuan. Hal ini bermakna kaum laki-laki sebenarnya juga dapat menekuni pekerjaan sebagai penenun. Namun, sampai saat ini keterlibatan kaum laki-laki dalam aktivitas menenun masih sangat terbatas, mereka hanya membantu pada tahapantahapan tertentu dalam menenun.

Bagi keluarga yang belum menguasai keterampilan ini dan ada anak mereka yang berminat mempelajarinya, maka mereka mengantarkan anak tersebut kepada orang yang dianggap paling mahir di kawasan ini, hasil kerjanya (produk) berkualitas, dan juga pernah mengikuti pelatihan yang terkait dengan aktivitas menenun (biasanya dilakukan oleh Dinas Perindustrian). Kegiatan pelatihan dilakukan secara tradisional, tanpa ada 
jadwal yang tetap, materi pelajaran yang jelas, kurikulum, modul, dan lain-lain yang biasanya ada dalam aktivitas pembelajaran formal. Hal ini terjadi karena guru yang mengajar bukanlah orang yang mendapatkan pengetahuan ini melalui institusi pendidikan tentang keterampilan ini (karena memang tidak tersedia institusinya), melainkan juga diwariskan secara tradisional. Cepat atau lambatnya menguasai keterampilan tersebut sangat bergantung dengan kemauan, daya tangkap, dan ketekunan anak yang belajar. Kegiatan ini dilaksanakan sampai anak tersebut mampu menguasainya, tanpa dibatasi waktu secara ketat. Meskipun biasanya ada rentang waktu yang diperkirakan anak-anak yang belajar mampu menguasainya, yaitu berkisar 3 hingga 4 bulan.

Pewarisanketerampilanmenenundilakukanoleh masyarakat Melayu bukan hanya bertujuan untuk melestarikan kerajinan tradisional saja, melainkan juga mempunyai nilai ekonomi. Pekerjaan sebagai penenun (perajin songket) menjadi salah satu pekerjaan yang dapat mendatangkan penghasilan bagi keluarga. Pekerjaan menenun sampai saat sekarang masih dilakukan secara tradisional dan tidak menggunakan mesin atau teknologi yang canggih, yang dikenal dengan istilah ATBM (Alat Tenun Bukan Mesin). Setiap tahapan dalam proses menenun dilakukan secara manual dan tidak dibantu oleh mesin. Proses yang manual ini tentu saja dapat melibatkan seluruh anggota keluarga.

Pewarisan menenun yang dilakukan oleh para perajin kepada generasi muda, meskipun hanya terbatas pada lingkungan keluarga mereka, namun dapat mendukung pelestarian kerajinan tradisional ini. Jika tidak mereka lakukan pewarisan tersebut dapat dipastikan budaya ini akan hilang, karena budaya merupakan proses pembelajaran oleh para pendukungnya (Kottak, 2010: 35). Sejalan dengan semangat otonomi daerah yang berupaya menggali berbagai potensi daerah, menjadikan kerajinan tenun sebagai salah satu kerajinan yang dikembangkan oleh Pemerintah Provinsi Riau untuk dijadikan sebagai produk khas Riau. Untuk itu, pemerintah membuat program dan kebijakan agar tercapainya tujuan sebagaimana yang tercantum dalam visi 
Riau 2020 (Visi Dan Misi Provinsi Riau, 2019). Program bantuan modal, alat tenun, gedung tempat menenun, program pelatihan, dan sebagainya dilakukan oleh pemerintah agar keterampilan ini dikuasai oleh masyarakat. Begitu juga dengan kebijakan untuk tercapainya tujuan tersebut, seperti penggunaan kain tenun dan baju Melayu pada hari tertentu bagi Aparatur Sipil Negara (ASN) dan pada event-event resmi, serta Gerakan Riau Bertanjak untuk mendongkrak pemasaran kain tenun (Amin, 2019). Tanjak merupakan produk turunan dari kain tenun yang pada masa lalu hanya dipakai oleh laki-laki sewaktu menikah. Pada saat sekarang Pemerintah Provinsi Riau mendorong penggunaan tanjak yang lebih luas, seperti dalam event-event resmi dan juga dijadikan sebagai cenderamata bagi tamu-tamu penting. Hal ini tidak hanya dilakukan di lingkungan pemerintahan, tetapi juga ditemukan di kampus-kampus, LSM, sekolah-sekolah, dan lain-lain.

\section{Menenun dan Kontribusi Ekonomi Rumah Tangga}

Tingkat ekonomi rumah tangga perajin songket sebagian besar adalah berpendapatan menengah ke bawah. Suami mereka melakukan berbagai jenis pekerjaan yang dapat menghasilkan uang. Pekerjaan yang ditekuni oleh suami mereka antara lain sebagai petani karet, nelayan, tukang bangunan, pembantu tukang, buruh perusahaan, usaha mandiri, dan lain-lain. Jenis pekerjaan tersebut merupakan mata pencarian utama yang mereka tekuni untuk memenuhi nafkah keluarga, namun pada kenyataannya mereka tidak terpaku hanya melakukan satu jenis pekerjaan saja, melainkan melakukan berbagai pekerjaan sesuai dengan kesempatan yang ada.

Dengan kondisi ekonomi rumah tangga di atas mengharuskan kaum perempuan (istri) ikut bekerja. Meskipun dalam pandangan budaya Melayu kepala rumah tangga dan tanggungjawabekonomiberada dipundaksuami, danpandangan ini umum berlaku di seluruh daerah Riau dan Indonesia (Djohan dkk., 2003; Widigdo, 2010). Namun, keikutsertaan kaum perempuan (istri) dalam aktivitas ekonomi bukanlah merupakan sesuatu yang "salah", sehingga pembagian kerja dalam rumah 
tangga perajin tenun tidaklah bersifat hitam-putih. Hal ini dapat dilihat sebagai model "kesatuan rumah tangga" yang tidak menganggap rumah tangga akan mengalokasikan sumberdaya secara merata berdasarkan gender. Secara tradisional, para ekonom dan analis kebijakan cenderung memandang rumah tangga sebagai sebuah unit yang menyatukan penghasilan dan mengalokasikan semua sumberdaya untuk memenuhi kebutuhan konsumsi, produksi dan investasi (The World Bank, 2005: 147-180). Keterlibatan perempuan dalam menopang penghasilan keluarga, menjadikan mereka dibebani pekerjaan ganda yaitu mengurus rumah tangga sekaligus ikut mencari nafkah. Perempuan memikul beban kerja ganda yang muncul dari pandangan yang bias gender dan budaya patriarki. Padahal pandangan tersebut merupakan hasil konstruksi sosial yang dilegitimasi oleh nilai-nilai budaya dan pemahaman terhadap ajaran agama (Islam) (Fakih, 1996; Megawangi, 1999; Nurmila, 2015). Legitimasi sumber inilah yang membuat mereka tidak merasa "dieksploitasi" oleh kaum laki-laki (suami) seperti yang dituduhkan oleh kelompok feminis (Megawangi, 1999: 117-135). Mereka melakukan semua pekerjaan tersebut dengan ikhlas dan dipandang sebagai menunaikan kewajiban dalam berumah tangga. Pemahaman ini diwariskan secara turun temurun dan diteguhkan oleh nilai budaya dalam masyarakat, sehingga seolah-olah hal tersebut adalah suatu "kebenaran" yang tidak dapat diperdebatkan dan diubah lagi.

Rumah tangga perajin tenun tidak memiliki pendapatan yang tetap dan pasti jumlahnya, semuanya bergantung dengan keadaan. Suami melakukan berbagai pekerjaan untuk mensiasati kondisi alam, seperti ketika hujan mereka tidak bisa menoreh getah, dan beralih menjadi buruh. Dengan kondisi ekonomi yang tidak pasti ini mereka harus mampu mengatur keperluan rumah tangga dengan baik, apalagi pada waktu pekerjaan utama tidak bisa dilakukan. Para perajin tenun melakukan pekerjaan tersebut untuk menopang ekonomi rumah tangga, baik sebagai penghasilan utama maupun sebagai penghasilan tambahan. Pola perilaku kerja ini berkaitan erat dengan dengan 
cara mereka mengalokasikan waktu dan tenaganya, antara bekerja mencari nafkah dan mengurus rumah tangga. Pola seperti ini ditemukan hampir pada seluruh rumah tangga yang ekonominya menengah ke bawah (Rostiyati, 2018; Simon, 2005; Umar \& Abdullahi, 2007).

Kontribusi perajin tenun dalam ekonomi rumah tangga menjadikan mereka memainkan peran yang diperhitungkan dalam pengambilan keputusan dalam keluarga. Dalam rumah tangga perajin songket muncul iklim demokrasi dalam membuat keputusan-keputusan besar. Mereka selalu dilibatkan oleh suami dalam mengambil keputusan, sehingga segala sesuatu diputuskan secara diskusi dan musyawarah, seperti dalam memutuskan untuk menyekolahkan anak, membeli perabot rumah tangga, membeli kendaraan, dan lain-lain (Zulkarnain, wawancara, 11 Oktober 2019). Hal ini terjadi karena para suami sadar betul bahwa istrinya amat membantu dalam memenuhi kebutuhan rumah tangga, sehingga suara mereka patut untuk didengar. Di samping itu, keluarga perajin tenun tidaklah menjalankan pembagian kerja secara ketat, artinya pekerjaan rumah tangga dikerjakan secara bersama-sama antara suami dan istri. Hal ini menunjukkan bahwa perempuan yang memiliki pendapatan atau akses ekonomi akan memiliki posisi tawar (bargaining position) terhadap suaminya dalam rumah tangga, sehingga kedudukan perempuan dalam rumah tangga tidak lagi marginal.

Peran manajemen perempuan (istri) dalam rumah tangga perajin tenun amat penting, di antaranya mereka harus mengatur kebutuhan rumah tangga antara keperluan sehari-hari, biaya pendidikan, dan kebutuhan lainnya. Untuk memenuhi kebutuhan sehari-hari tidak jarang mereka berhutang di kedai langganan, terutama pada waktu suami mereka tidak dapat melakukan pekerjaan utama. Hutang tersebut baru dibayar setelah mereka mendapatkan uang. Biaya pendidikan tidak begitu mahal, karena di daerah ini semuanya sekolah negeri yang disubsidi oleh pemerintah. Mereka baru akan kesulitan ketika anak mereka menempuh pendidikan tinggi, karena harus pergi ke kota, seperti ke Bengkalis, Pekanbaru, dan sebagainya. 
Mereka juga memerlukan berbagai keperluan lain sebagai tuntutan zaman, seperti kendaraan, hand phone, televisi, dan lain-lain. Untuk memenuhi kebutuhan penunjang ini mereka mendapatkannya secara kredit dengan sistem pembayaran secara berangsur-angsur. Ini satu-satunya strategi yang dapat mereka lakukan untuk memilikinya. Menurut informan (wawancara, 13 Oktober 2019), jika menunggu uang terkumpul dan membelinya secara kontan, maka itu dirasakan tidak mungkin, karena setiap hari ada saja keperluan sehingga sulit sekali mengumpulkan uang. Pada satu sisi, kredit ini memberatkan beban ekonomi mereka setiap bulannya, namun di sisi lain mereka merasa terbantu dengan membayar secara cicilan mereka dapat memiliki suatu barang yang harganya mahal. Dalam kenyataannya, ada juga rumah tangga tertentu yang kreditnya macet, sehingga pembayarannya menjadi tertunda. Hal ini menjadi catatan bagi yang memberi kredit sehingga yang bersangkutan menjadi kurang dipercaya. Keadaan seperti ini mempersulit kondisi rumah tangga, karena ia tidak akan mendapatkan kredit atau berhutang dengan orang lain sehingga keperluan-keperluan yang mendesak sulit diatasi.

Kebutuhan-kebutuhan ini akan meningkat ketika menyambut Idul Fitri. Tradisi masyarakat bahwa untuk menyambut Idul Fitri harus dengan sesuatu yang baru, baju baru, kursi baru, mencat rumah, membuat kue-kue, dan sebagainya. Dalam kondisi ini dan demi memenuhi keperluan-keperluan tersebut mereka akan berupaya mencari tempat berhutang atau sudah memesannya jauh-jauh hari dengan langganan mereka berkredit. Kondisi serupa juga terjadi pada tahun ajaran baru sekolah, anak-anak mereka harus memakai baju baru, rok/ celana baru, dasi baru, topi baru, sepatu baru, kaos kaki baru, dan tas baru.

Dengan kondisi ekonomi yang serba terbatas mereka berusaha untuk memenuhi kebutuhan, baik kebutuhan seharihari, pendidikan, maupun berkaitan dengan gaya hidup. Mereka juga harus memenuhi kebutuhan yang muncul dari kebiasaan yang ada di tengah masyarakat. Oleh karena itu, kontribusi istri 
dalam perekonomian dapat membantu dalam memenuhi berbagai kebutuhan dalam rumah tangga. Hubungan dan komunikasi yang baik antara suami dan istri dalam rumah tangga dapat mengatasi berbagai persoalan ekonomi yang dihadapi dimana pada akhirakhir ini menunjukkan harga barang senantiasa menaik.

Penghasilan yang diperoleh dari pekerjaan menenun ini cukup lumayan dan dapat memenuhi sebagian dari kebutuhan rumah tangga dan keluarga, terutama bagi keluarga yang suaminya tidak memiliki pekerjaan atau penghasilan yang tetap (Marliana, wawancara, 7-13 Oktober 2019). Berkurangnya pendapatan para suami - khususnya di Dusun Muara Laut sebagai dampak dari dilarangnya kegiatan illegal logging dan penjualan minyak illegal. Di samping itu, kegiatan sebagai nelayan sudah tidak mendatangkan hasil yang memadai seperti masa lalu (Wahab, wawancara, 05 Oktober 2019). Jadi, secara tidak langsung mereka sangat bergantung dengan pendapatan istri yang menekuni pekerjaan sebagai perajin tenun. Dengan demikian, kontribusi ekonomi yang diberikan oleh kaum perempuan sangat berarti dalam rumah tangga, dan tidak jarang pendapatan mereka dijadikan tulang punggung keluarga (Zuraida, wawancara, 12 Oktober 2019).

Kontribusi kaum perempuan perajin tenun terhadap peningkatan ekonomi keluarga sangat besar dan tidak diragukan lagi. Mereka mengerjakan kain tenun yang dipesan oleh konsumen dengan kualitas, motif, dan warna yang diinginkan. Kualitas yang berbeda tentu saja mempunyai harga yang lebih tinggi, ini ditandai dengan seberapa banyak benang emas (yang dijadikan motif) yang digunakan pada kain tenun tersebut. Di samping itu, mereka juga memproduk kain tenun untuk seragam suami-istri yang sekarang harganya berkisar Rp.1.500.000.

Besarnya penghasilan yang diperoleh dari kegiatan menenun ini sangat bergantung dengan kemampuan, kecepatan, dan ketekunan seseorang dalam mengerjakannya. Tidak ada kepastian tentang seberapa lama seseorang akan menyelesaikan satu tenunan atau satu kain tenun, semuanya bergantung dengan seberapa banyak waktu yang disediakan untuk mengerjakannya. 
Semakin banyak waktu yang disediakan, semakin cepat siapnya satu tenunan tersebut (Antik, wawancara, 08 Oktober 2019). Semakin banyak hasil tenun yang diproduk dalam setiap bulannya, tentu akan semakin besar sumbangannya terhadap penghasilan keluarga. Setiap perajin mempunyai waktu dan kemampuan yang berbeda dalam menyelesaikan satu helai kain tenun, ada yang memakan waktu 1 minggu, 10 hari, 1 bulan dan seterusnya.

Motivasi mereka dalam bekerja adalah untuk membantu dalam memenuhi keperluan rumah tangga, terutama yang bersifat ekonomis. Pada masyarakat seperti ini, perempuan bekerja di luar rumah tidak dipandang sebagai sesuatu yang aib atau memalukan, karena laki-laki dan perempuan dipandang sama-sama harus bekerja, sekalipun tanggung jawab mencari nafkah tetap berada di tangan suami (Ernita, wawancara, 08 Oktober 2019). Keadaan seperti ini sebenarnya sangat memberatkan kaum perempuan, di mana mereka harus melakukan pekerjaan yang lebih banyak, beragam, dan mereka juga harus bekerja lebih lama dibanding laki-laki. Pada satu sisi mereka dituntut untuk melakukan pekerjaan rumah tangga (domestik) dengan baik, dan pada sisi lain mereka juga harus membantu suami mencari nafkah, baik bekerja sebagai pedagang, petani, peladang, perajin, penjahit, dan lain-lain. Namun, bagi mereka kegiatan rutinitas ini lebih dipandang sebagai kewajiban daripada pembagian kerja yang berdasarkan gender (Nimarni, Wawancara, 7-13 Oktober 2019).

Selain menenun, banyak fakta di lapangan yang memperlihatkan bahwa perempuan memiliki dan menjalankan usaha sendiri di rumah untuk menambah penghasilan, seperti membuka warung, jasa penjahitan, dan pengolahan makanan (Agustina, wawancara, 13 Oktober 2019). Ketiga jenis pekerjaan ini seringkali dianggap sebagai kerja "khas" perempuan. Berdasarkan penjelasan tersebut, dapatlah dibuat suatu pengelompokan jenis usaha yang ditekuni perempuan Melayu, yaitu; (1) pekerjaan tanpa upah dalam sistem produksi keluarga, (2) pekerjaan upahan dalam hubungan yang sifatnya informal, dan (3) usaha mandiri yang dijalankan sebagai penambah penghasilan. 
Fenomena di atas menunjukkan bahwa kaum perempuan sudah terbiasa bekerja atau menjalankan usaha sendiri, baik dalam bentuk usaha mandiri, usaha keluarga, atau kombinasi keduanya. Kerja sebagai home worker, home-based worker, buruh upahan, dan self-employed dalam skala mikro menjadi pilihan kebanyakan perempuan karena dipandang memberikan fleksibilitas antara mengerjakan kegiatan domestik sekaligus kerja produktif yang memberikan penghasilan (cash income). Selain itu, juga memberi kesempatan dan waktu untuk memperoleh tambahan penghasilan lewat usaha-usaha lainnya.

\section{Simpulan}

Tenun khas Melayu Riau merupakan peninggalan budaya Kerajaan Siak dan berkembang lebih pesat pada era otonomi daerah. Menenun pada masa sekarang tidak hanya memiliki nilai ekonomis, namun juga memiliki makna bagi pearis dan pengembangan kerajinan tradisional Melayu Riau. Pekerjaan menenun menjadi salah satu pilihan perempuan Melayu karena pekerjaan ini dapat dilakukan di rumah sembari mengerjakan pekerjaan domestik. Dalam pandangan budaya Melayu, perempuan (istri) bertanggung jawab terhadap pekerjaan domestik dan suami bertanggung jawab dalam memenuhi nafkah keluarga. Pekerjaan menenun memberikan perempuan beban ganda yaitu mengurus keluarga sekaligus bertanggungjawab atas pekerjaan domestik rumah tangga. Rutinitas ini dipahami para informan sebagai kewajiban daripada menyadarinya sebagai ketimpangan berbasis gender. Keterampilan menenun diwariskan secara turun temurun oleh keluarga perajin kepada anak perempuan mereka secara tradisional. Dan pada masa sekarang dilakukan pelatihan pada unit usaha tenun yang melibatkan generasi muda baik laki-laki maupun perempuan di beberapa kawasan bekas Kerajaan Siak, seperti di Kabupaten Siak, Kabupaten Bengkalis, Kota Dumai, dan juga Kota Pekanbaru dalam skala usaha mikro.

Perempuan Melayu sudah sejak lama menekuni berbagai pekerjaan yang dapat menambah pendapatan, baikdilakukansecara 
mandiri maupun membantu suami. Peran ekonomi perempuan perajin tenun sering dinyatakan sebagai peran tambahan, namun dalam kenyataannya tidak jarang perempuan sebagai penopang utama dalam ekonomi keluarga. Peran ekonomi perempuan dalam kegiatannya memenun, memberikan dampak peningkatan peran perempuan dalam pengambilan keputusan keluarga di mana keputusan-keputusan besar dalam rumah tangga memberikan ruang yang cukup bagi keterlibatan perempuan.

Pemerintah Provinsi Riau mendukung industri tenun melalui berbagai kebijakan, mulai dari bantuan modal, pelatihan, danjuga pemasaran. Dengan demikian, dorongan dan dukungan pemerintah terhadap kerajinan ini memberikan manfaat ganda yaitu pada satu sisi aktivitas ini dapat mendatangkan nilai ekonomi bagi keluarga, dan pada sisi lain warisan tradisional budaya Melayu tetap terlestarikan. 


\section{DAFTAR PUSTAKA}

Amin. (2019, Oktober). Dinas Kebudayaan akan Menggalakkan "Riau Bertanjak" [Https://www.cakaplah.com/ berita / baca/2019/10/03/ dinas-kebudayaan-akanmenggalakkan-riau-bertanjak\#sthash.xa1w7ycB.dpbs].

Andani, N. (2017). "Pemberdayaan Masyarakat Berbasis Ekonomi di Kelurahan Maharatu Kecamatan Marpoyan Damai Pekanbaru (Studi Kasus Pemberdayaan Perajin Tenun Songket Khas Melayu Winda)". Universitas Islam Negeri Syarif Hidayatullah.

Anshori, D. S., Engkos, K., \& Sarimaya, F. (Ed.). (1997). Membincangkan Feminisme: Refleksi Muslimah Atas Peran Sosial Kaum Wanita. Pustaka Hidayah.

Ayesha, I. (2016). “Perilaku Pengrajin Gula Merah Tebu Tradisional di Nagari Bukik Batabuah, Kecamatan Canduang, Kabupaten Agam". Jurnal Pembangunan Nagari, 1(2), 89-102.

Dekranasda Provinsi Riau. (2008). Khazanah Kerajinan Melayu Riau. Dekranasda bekerjasama dengan Balai Kajian dan Pengembangan Budaya Melayu Riau.

Dewayanti, R., \& Chotim, E. E. (2004). Marjinalisasi dan Eksploitasi Perempuan Usaha Mikro di Perdesaan Jawa. Akatiga.

Dewayanti, R., Mulyoutami, E. P., \& Susilowati, R. (2003). Persoalan Usaha dan Pengorganisasian Perempuan Usaha Kecil Studi Kasus: Usaha Genteng di Klaten dan Usaha Gula Kelapa di Banyumas. Akatiga.

Djohan, S. M., Hasbullah, \& Thamrin, H. (2003). Identifikasi dan Penataan Sumber Daya Perempuan (Studi Rencana Kerja Pemecahan Masalah Pembangunan Sumber Daya Manusia Perempuan). Pemerintah Provinsi Riau.

Egayanti, A., Sukidin, S., \& Ani, H. M. (2018). "Perilaku Kewirausahaan Pengrajin Gerabah di Kecamatan Besuk Kabupaten Probolinggo". Jurnal Pendidikan Ekonomi: Jurnal Ilmiah Ilmu Pendidikan, Ilmu Ekonomi dan Ilmu Sosial, 11(2), 44-50. https:// doi.org/10.19184/jpe.v11i2.6446

Fakih, M. (1996). Analisis Gender dan Transformasi Sosial. Pustaka Pelajar.

Fakih, M., Megawangi, R., Asa, S., Saefuddin, A. M., \& Wahid, M. N. H. (1996). Membincang Feminisme: Diskursus Gender Perspektif Islam. Risalah Gusti. 
Fariyanti, A. (2008). "Perilaku Ekonomi Rumahtangga Petani Sayuran Dalam Menghadapi Risiko Produksi dan Harga Produk di Kecamatan Pangalengan Kabupaten Bandung" [Disertasi]. Institut Pertanian Bogor.

Harun AR, M. Q. (2015). “Rethinking Peran Perempuan Dalam Keluarga". KARSA: Jurnal Sosial dan Budaya Keislaman, 23(1), 17-35. https://doi.org/10.19105/ karsa.v23i1.607

Husin, L., \& Sari, D. W. (2011). "Perilaku Ekonomi Rumah Tangga Petani Karet di Prabumulih dalam Alokasi Tenaga Kerja, Produksi dan Konsumsi". Universitas Brawijaya.

Ihromi, T. O. (Ed.). (1995). Kajian Perempuan dalam Pembangunan. Yayasan Obor Indonesia.

Ilyas, Y. (1997). Feminisme Dalam Kajian Tafsir Al-Qur'an Klasik dan Kontemporer. Pustaka Pelajar.

Kottak, C. P. (2010). Window on Humanity: A Concise Introduction to Anthropology (4th ed). McGraw-Hill.

Kusnadi, N. (2005). "Perilaku Ekonomi Rumah Tangga Petani Dalam Pasar Persaingan Tidak Sempurna di Beberapa Provinsi di Indonesia" [Disertasi]. Institut Pertanian Bogor.

Luthfi, M., MS., S., \& Ghalib, W. (Ed.). (1977). Sejarah Riau. Pemda Tk. I Riau.

Masud, J., \& Hamid, T. A. T. A. (2004). “Wanita Ketua isi Rumah: Isu dan Cabaran". Dalam Golongan Berpendapatan Rendah Realiti dan Cabaran. Universiti Putera Malaysia.

Mayaswari, W. H., \& Yasa, I. G. W. M. (2015). "Peran Ganda Pedagang Perempuan di Pasar Seni Mertha Nadi Legian, Bali". Populasi, 23(2), 71-84. https://doi.org/10.22146/ jp.15696

Megawangi, R. (1999). Membiarkan Berbeda? Sudut Pandang Baru Tentang Relasi Gender (2nd edition). Mizan.

Nurmila, N. (2015). "Pengaruh Budaya Patriarki Terhadap Pemahaman Agama dan Pembentukan Budaya". KARSA: Jurnal Sosial dan Budaya Keislaman, 23(1), 2-16. https:/ / doi. org/10.19105/karsa.v23i1.606

Nursiah, T., Kusnadi, N., \& Burhanuddin, B. (2017). “Perilaku Kewirausahaan pada Usaha Mikro Kecil (UMK) Tempe di Bogor Jawa Barat". Jurnal Agribisnis Indonesia, 3(2), 145158. https://doi.org/10.29244/jai.2015.3.2.145-158 
Pancasasti, R. (2008). “Analisis Perilaku Ekonomi Rumah Tangga dan Peluang Kemiskinan Nelayan Tradisional (Studi Kasus: Rumahtangga Nelayan Tradisional di Kecamatan Kasemen Kabupaten Serang Propinsi Banten)" [Thesis]. Institut Pertanian Bogor.

Prasetyo, P. E. (2007). "Perilaku Perajin Dalam Meningkatkan Kinerja Pasar". Jurnal Ekonomi Pembangunan: Kajian Masalah Ekonomi dan Pembangunan, 8(2), 163-176. https:// doi.org/10.23917/jep.v8i2.1039

Puspitawati, H., Simanjuntak, M., \& Hayati, L. (2012). “Kontribusi Ekonomi dan Peran Ganda Perempuan Serta Pengaruhnya Terhadap Kesejahteraan Subjektif". Jurnal Ilmu Keluarga \& Konsumen, 5(1), 11-18.

Rizky, A. (2008). "Strategi Jitu Investasi di UMK: Optimalisasi Kontribusi UMK dalam Makroekonomi Indonesia". Launching dan Seminar BMT Permodalan, Jakarta.

Rostiyati, A. (2018). "Peran Ganda Perempuan Nelayan di Desa Muara Gading Mas Lampung Timur". Patanjala: Jurnal Penelitian Sejarah dan Budaya, 10(2), 187-202. https://doi. org/10.30959/ patanjala.v10i2.373

Sari, M. (2015). Tenunan Songket Melayu Riau di Kota Dumai Provinsi Riau. Universitas Negeri Padang.

Siddik, M. S., Amiruddin, A., \& Juniarsih, N. (2013). “Perilaku Ekonomi Masyarakat Miskin di Sekitar Kawasan Hutan Gunung Rinjani Pulau Lombok". Jurnal Agribisnis Indonesia, 1(1), 27-38. https:/ / doi.org/10.29244/jai.2013.1.1.27-38

Simon, D. (2005). Fifty Key Thinkers on Development. Routledge Taylor \& Francis Group.

Suwati, K. (1996). Kain Songket Indonesia. Djambatan.

The World Bank. (2005). Pembangunan Berperspektif Gender (T. Marlita, Penerj.; First). Dian Rakyat.

Umar, M. Z., \& Abdullahi, A. (2007). “Women Empowerment and Nigerias Development: Perspectives, Challenges And Prospects". Journal of Research in National Development, 5(2).

Visi Dan Misi Provinsi Riau. (2019, Februari 8). [Https://www. riau.go.id/home/content/858/visi-dan-misi].

Widigdo, I. (2010). "Etos Kerja Wanita Pengrajin Batik Tulis". Jurnal Dinamika Manajemen, 1(2), 104-111. 